\title{
LAWS OF RATIFICATION OF AN INTERNATIONAL TREATY IN INDONESIAN LAWS HIERARCHY
}

\author{
Noor Sidharta \\ Indonesian's Witness and Victim Protection Agency \\ sidhartanoor@gmail.com
}

\begin{abstract}
This journal article discusses the laws of ratification of an international treaty in Indonesian laws hierarchy. This journal uses a normative research approach where a draft agreement and laws are used as primary data apart from the laws and international treaties. There are some issues that still unsettled related to the legal status of the laws of ratification of an international treaty that have impacts in the implementation of the treaty. The laws of ratification of an international treaty now is still classified as general laws whose the content of the norm has been discussed by the People's Representatives Council, therefore the laws of ratification of an international treaty automatically become the object of Judicial Review at the Constitutional Court of the Republic of Indonesia. The cancellation of the laws of ratification of an international treaty impacts the cancellation of the deal on the treaty and it has failed the pacta sunt servanda principle, which becomes the basis of a treaty. To solve problems related to the cancellation of laws of ratification of an international treaty at the Constitutional Court, there are several efforts on state administration by classifying the laws which differ the general laws from the laws whose contents are related to the international treaty. Furthermore, a progressive new method on the state administration is needed by giving a Judicial Preview right to the Constitutional Court to conduct a review on the bill of the ratification of an international treaty based on its suitability to the constitution.
\end{abstract}

Keywords : Judicial Preview, Hierarchy, Laws, Dualism, Treaties 


\section{INTRODUCTION}

\subsection{Background of the Problem}

Every country in this world cannot stand alone without any help and support from other countries. A relationship between countries or diplomatic relationship whose aim is to support countries' agenda, is realized through a treaty or international treaty. The important meaning of an international treaty for Indonesia is realized through the state's constitution, that is the 1945 Constitution of the Republic of Indonesia, which includes the clause about international treaty in Article 11 of the 1945 Constitution of the State of Republic of Indonesia, which states as follow:

(1) The President with the approval of the People's Representative Council declares war, makes peace and concludes treaties with other countries.

(2) The President when concluding other international treaties that give rise to extensive and fundamental consequences to the life of the people related to the financial burden of the state, and/or compelling amendment or enactment of laws shall be with the approval of the People's Representative Council.

(3) Further provisions regarding international treaties shall be regulated by laws.

Before the amendment of the 1945 Constitution of the State of Republic of Indonesia, the Article 11 states "the President with the approval of the People's Representatives Council declares war, makes peace and concludes treaty with other countries". In Indonesia, international treaties has faced three different legal regimes. ${ }^{1}$ The first period $1945-1960$ is when the international treaty is based on three constitutions on those periods, that are the 1945 Constitution of the State of Republic of Indonesia, the 1949 Constitution of the Union of Republic of Indonesia, and the 1950 Constitution. The second period is between 19602000, although it is based on the 1945 Constitution of the State of the Republic of Indonesia, the international treaty is submtitted to the condition ruled by Presidential Letter No. 2826 year 196o. Since 2000, the law Number 24 year 2000 
about International Treaties which is a mandate from the 1945 Constitution of the State of Republic of Indonesia is implemented.

As the implementation on the provision of Article 11 of the 1945 Constitution of the State of the Republic of Indonesia, the law of the Republic of Indonesia Number 24 Year 2000 about International Treaties has been applied. On Article 3 of International Treaties, it is mentioned that the Government of the Republic of Indonesia is submitted to international treaties through the following ways:

a. Signing;

b. Ratification;

c. The exchange of treaty documents/diplomatic notes;

d. Other ways as agreed by parties to international treaties.

Ratification of international treaties is done by the laws or the presidential decree. The ratification of international treaties is done by the laws with the following conditions:

a. Political problem, peace, defense, and national security;

b. Regional change or the border setting of the Republic of Indonesia;

c. The sovereignty or sovereign rights of a country;

d. Human rights and living environment;

e. Establishment of a new law principle;

f. The loan and/or foreign grants.

The ratification of international treaties whose the content is apart from the aforementioned points is done by the Presidential Decree. In relation to those provisions, it is important to be noticed that a regulation which controls the laws and regulation is the law of the Republic of Indonesia Number 12 Year 2011 about the Establishment of the Laws and Regulation.

It is mentioned in Article 1 Number 3 about the Law of the Establishment of the Laws and Regulation, it states that laws are laws and regulation established by the People's Representatives Council with the approval of the President. Then, it is further explained in Article 10 of that law, the contents which are subject to the law are: The further regulation about the provision of the 1945 Constitution 
of the State of the Republic of Indonesia; an order of a law to be regulated in a law; ratification of particular international treaties; the follow up on verdicts of the Constitutional Court; and/or compliance of the legal needs of citizens and the follow up on verdicts of the Constitutional Court.

Both the constitution and the provisions of the law (Law of the Establishment of the Laws and Regulation \& Law of International Treaties) have ensured that ratification of international treaties is part of the national rule of law through ratification. However, it does not mean problems do not exist. The main unanswered aspect both in the constitution and in the provision of the law in Indonesia is there is not any classification of law, which can be cancelled by the Constitution Court at any time. In fact, the content of the law migh be different.

As it is mentioned in the 1945 Constitution of the State of the Republic of Indonesia in Article $24 \mathrm{C}$ that the Consitutional Court is authorized to hear at the first and the final level whose verdict is final to review laws toward the 1945 Constitution, to decide disputes over authority of state institutions whose authority is given by the 1945 Constitution of the State of the Republic of Indonesia, to decide disbandment of political parties, and to decide disputes on results of the general election. Authority about the final level whose verdict is final to review laws toward the 1945 Constitution including the international treaties which are ratified into a law. Article 7 (1) of the law of the Republic of Indonesia Number 24 Year 2000 about International Treaties which has been applied don't have a clear about international treaties position on laws clasification ini Indonesia. Based on practice international treaties which are ratified into a law classification such as a law Number 38 Year 2008 about the ratification of ASEAN Charter. It means if a legal product whose content is classified into the content of laws, including the international treaties which are ratified into a law, it can be review at a Constitutional Court.

In history of international treaties done by Indonesia, for the first time Indonesia faced a Judicial Review case related to the ratification of an international treaty in 2011 when the Constitutional Court accepted a petition for judicial review of a law Number 38 Year 2008 about the ratification of ASEAN Charter 
filed by Institute for Global Justice dan several mass organizations such as trade union, fishermen's union etc. ${ }^{2}$ Reasons for filing a Judicial Review on the law of the ratification of Asean Charter as written in the petition are: 3

a) ASEAN is regarded as neocolonialism and imperialism in form of international organization and proposes ASEAN as economic community as the strategy.

b) By using the economic agreement binding the countries through ASEAN Charter, a free trade agreement is done between the member and other countries who are not part of ASEAN, which are considered by the petitioners as a threat for indonesia's economic sovereignty.

c) The idea of ASEAN from economic perspective by using free trade concept and based on the single production, is a neoliberalism idea written in ASEAN Charter Article 1 paragraph (5), which states:

To create a single market and production base which is stable prosperous, highly competitive and economically integrated with efective falicitation for trade and investment in which there is free low of goods, services and investment, facilitated movement of business persons, professionals, talents and labours, and free low of capital ${ }^{4}$

Article 2 paragraph (2) and states:

Adherence to multilateral trade rules and ASEAN's rules-based regimes for efective implementation of economic commitment and progressive redution towards elimination of all barriers to regional economic integration, in a market driven economy

The aforementioned petition says the Constitutional Court has to declare that The Law No. 38 Year 2008 Article 1 paragraph (5) and Article 2 paragraph (2) n Charter of the Association of Southeast Asian Nations, have violated the Article 27 paragraph (2) and Article 33 paragraph (1) of the 1945 Constitution of the State of the Republic of Indonesia, and the integration of free market creates free trades which violates the economic sovereignty of a country, so the constitution of the ratification needs to be cancelled. Related to the petition, the Constitutional Court decides that the petition is unreasonable based on the law.

2 Khaerudin, "MK Diminta Batalkan Ratifikasi Piagam Asean," Kompas.Com, 2012, http://internasional.kompas.com/ $\mathrm{read} / 2012 / 11 / 23 / 2139259 /$ MK.Diminta.Batalkan.Ratifikasi.Piagam. Asean.

3 Simon Tumanggor, Judicial Review Undang-Undang Pengesahan Piagam Perhimpunan Bangsa-Bangsa Asia Tenggara Jendela Informasi Bidang Hukum Bidang Perdagangan (Jakarta: Kementerian Dalam Negeri RI, 2011), 3.

4 Judicial Review Law Number 38 of 2008 on Ratification of the Association of Southeast Asian Nations against the 1945 Constitution, No. 33/PUU-IX/2011 (2011). Decision No. 33/PUU-IX/2011. 
From that case, if there is law of an International which has been signed and ratified and suddenly it got cancelled by the Constitutional Court, the process is not effective for the international diplomatic. Indonesia might lose the internationl trust since that case can be taken as a representative of Indonesia that Indonesia is an inconsistent states where the decision in the beginning until the end of the negotiation is consent to be bound in an international treaty, even Indonesia can get a penalty if there is a clause about the a penalty for withdrawling from an international treaty. The absence of classification for a law where a Judicial Review can be implemented becomes a sign that there has not a any way to solve disagreement between the laws and regulation and the regulations of the international treaty.

\subsection{Formulation of the Problem}

Based on the aforementioned fact in the previous point, the researcher formulates the the followiing research questions:

1. How is the laws of ratification of international treaties in Indonesian law hierarchy?

2. What steps that should be done to avoid the cancellation of the laws of ratification of international treaties through a Judicial Review at the Constitutional Court?

\subsection{Method}

This research is a normative research where a draft agreement and laws are used as primary data apart from the laws and international treaties. The previous research such as articles journal and dissertation, legal materials or written data such as legal codes, the courts' verdict, books, journal, magazines, newspaper, and other legal materials are used in the present study.

In relation to the problem about the laws of ratification of international treaties, the researcher uses Theory of Sovereignty to analyse the phenomena and problems related to the laws of ratification of international treaties. 


\subsection{Theory of Sovereignty}

Henry C Black defines a country as follow:

A country is group of people who permanently live in a particular teritory and bounded by the norm used in the country. That country runs its sovereignty independently and takes control the people and the resource inside the border area. Then the country is able to conduct a war and peace and concludes international relations with international communities. ${ }^{5}$

From the above definition, sovereignty becomes one of main elements to establish a country. Jean Bodin states that sovereignty is an attribute and a special character of a country. Without any sovereignty, a country does not exist. ${ }^{6}$

A sovereign state means there is not any higher power than the power of the state itself. In other words, a country has a single monopoly in that country. This supreme administrative space is limited by the border of the country which means the highest authority of a country is only available within its border. A country is the most important subject of an International Law (par Excellence) rather than other subjects. As a subject of international law, a country has rights and responsibilities under the international law. ${ }^{7}$

Based on Boer Mauna about the definition of sovereignity, ${ }^{8}$ where Boer Mauna explains the positive and negative impacts of a sovereignty.

1. The negative meaning of a sovereignty, it means that a country is not subject to the provisions of an international law whose status is higher. A sovereignty means a country is not subject to any power without the approval of that country.

2. The positive meaning of a sovereignty gives a position called as the supreme leader of the country. This is called full authority of a country and soverignty gives power/authority for the country to exploit the natural resources in its national teritory for the public welfare which is called as permanent sovereignty of the natural resources.

\footnotetext{
Huala Adolf, Aspek-Aspek Negara Dalam Hukum Internasional (Jakarta: Rajawali Press, 1991), 1-2.

Fred Isjwara, Pengantar Ilmu Politik (Bandung: Binacipta, 1996), 89.

Mochtar Kusumaatmadja, Pengantar Hukum Internasional, Buku I Bagian Umum (Jakarta: Binacipta, 2010), 16-17.

${ }^{8}$ Boer Mauna, Hukum Internasional. Pengertian, Peranan Dan Fungsi Dalam Era Dinamika Global (Bandung: Alumni, 2005), 25.
} 


\section{RESULT AND DISCUSSION}

\subsection{Problem of the Status of the Laws of Ratification of an International Treaty}

There are several problems about the laws of ratification of international treaties which has not been solved in order to guarantee its implementation, those problems are:

1. Law No. 24 Year 2000 about International Treaties which is not clear to explain the international treaties in the law system, but it only states that the international treaties are ratified by the law/Presidential decree without any further explanation about the meaning and consequences for the laws in Indonesia.

2. Another problem is in the hierarchy of the laws, as it is written in Article 7 paragraph (1) of the Law of the Establishment of the Laws and Regulation which does not explain detail of the international treaties in national law. If the manifestation of the ratification of the international treaties is in form of laws, it means the laws of the international treaties can be done through judicial review and the worst consequence is that laws can be cancelled and is not in line with the constitution or the 1945 Constitution of the State of the Republic of Indonesia. The consequence of the withdrawal of the international treaties can give a bad implication toward the foreign policy and weaken the position of Ministry of Foreign Affairs as a leader of a state diplomatic.

3. The Dualism Doctrine used by Indonesia can not give a clear position for international treaties in the national law hierarchy. This Dualism Doctrine places the international treaty outside the law hierarchy. Moreover, it seems like a compulsion placing the laws of ratification of international treaties into the law (in the hierarchy of the regulation of national law) because there is not any specific classification for the laws of ratification of international treaties. 


\subsection{International Treaties in the Hieararchy of Regulation of National} Laws

International treaties agreed and signed by Indonesia, based on Article 1 paragraph 3 of the Law of the Republic of Indonesia No. 12 Year 2011 about the establishment/formation of the Establishment of Regulation of Law become a content material of law, the following are related materials as mentioned in Article 10:

a. Further regulations about provisions in the 1945 Constitution of the State of the Republic of Indonesia;

b. The order of the law to be ordered by the law;

c. The ratification of particular international treaties;

d. The follow up on verdicts of the Constitutional Court; and/or

e. The compliance of legal need in society.

As the implementation from the mandate of the 1945 Constitution of the State of the Republic of Indonesia about international treaties, the Law of the Republic of Indonesia No. 24 Year 2004 is applied. It is about the International Treaties as a standard rule for international treaties in Indonesia. In the law in Article 3, it is mentioned that the Government of the Republic of Indonesia binds itself to the international treaties. The ratification of international treaties is done by the law if it relates to:

a. Political problem, peace, defense, and national security;

b. Regional change or the border setting of the Republic of Indonesia;

c. The sovereignty or sovereign rights of a country;

d. Human rights and living environment;

e. The establishment of a new law principle;

f. The loan and/or foreign grants.

The international ratification whose content is not available in the above explanation is done by Presidential Decree. In relation to that provision, the 
regulation which rules the regulation of law that needs to be known, that is the Law of the Republic of Indonesia No. 12 Year 2011 about the Establishment of the Regulation of Law.

In Indonesian legal system, there is only one law, that is the legal system established by the People's Representatives Council, with the approval of the President and agreed by the President. Besides, there is not any other laws established by other central or district institutions, therefore both central and district laws are not available in Indonesia. 9 There are provisions which underlie the establishment of laws in Indonesia such as:

1. Article 5 paragraph (1), Article 20, Article 21, Article 22 D paragraph (1), and Article 22 D paragraph (2) of the 1945 Constitution of the State of the Republic of Indonesia;

2. The Law of the Republic of Indonesia No. 12 Year 2011 about the establishment of Regulation of the law;

3. The Law of the Republic of Indonesia No. 17 Year 2014 about the People's Consultative Assembly, the People Representatives Council, the Regional Representatives Council, and Regional People Representatives Council.

4. Presidential Regulation of the Republic of Indonesia No. 87 Year 2014 about the Implementing Regulation No. 12 Year 2011 about the establishment of the regulation of law;

5. The Regulation of the House of Representatives Council of the Republic of Indonesia No. 1/DPRRI/2009 about the code of conduct.

6. The Regulation of the House of Representatives Council of the Republic of Indonesia No. 1 Year 2012 about the procedures for National Legislation Program;

7. The Regulation of the Representatives Council of Republic of Indonesia No. 2 Year 2012 about the Procedures of Bill's Preparation;

8. The verdicts of the Constitutional Court No. 92/PUU-X/2012 about the Judicial Review of the Law No. 27 Year 2009 about the People's Consultative

9 Maria Farida Indrati, Ilmu Perundang-Undangan (1). (Jenis, Fungsi, Materi Muatan) (Yogyakarta: Kanisius, 2007$), 53$. 
Assembly, the Representatives Council, the Regional Representatives, and the Regional People Representatives and the Law No. 12 Year 2011 about the Establishment of Regulation of Law (UUP3).

In other words, the international treaties which have been ratified by Indonesia is included in the nomenclature and law as it is has been legally defined by the Representatives Council of the Republic of Indonesia.

\subsection{The Sovereignty of a Country Vs International Treaty}

In Article 1 number $3 \mathrm{UUP}_{3}$, it is mentioned that a law is a regulation of law which is established by the People's Representatives with the approval of the President. Then in Article 10 of the Law of the Establishment of the Laws and Regulation, it is further explained that the content needed to be regulated by the law consists: the further regulation about the provision of the 1945 Constitution of the State of the Republic of Indonesia; the order of the law to be ordered by a law; the ratification of an international treaty; the follow up on the Constitutional Court's verdicts, and/or the compliance of legal needs in society and the follow up on the Constitutional Court's verdicts.

Both the constitution and the provision of Law of the Establishment of the Laws and Regulation have guaranteed the ratification of the international treaty which becomes part of the national legal provision through ratification. However, it does not mean there is no any problem at all. The main unanswered problem both in the constitution and the provisions of the laws in Indonesia is the absence of classification of laws which becomes the object of Judicial Review at the Constitution Court, as it is known that the contents of the laws are different.

As it is written on the 1945 Constitution of the State of the Republic of Indonesia in Article $24 \mathrm{C}$ that the Constitution Court is authorized to hear at the first and the final level whose the verdict is final to examine laws towards the 1945 Constitution, to resolve the dispute whose authorities are given by the 1945 Constitution of the State of the Republic of Indonesia, to decide on the 
dissolution of political parties, and to decide on disputes about the result of the general election, it means any kind of content of a legal product, as long as it is in form of laws, it can be reviewed by the Constitutional Court, the authority of the Judicial Review of the Constitutional Court is one of the main problem on the implementation of an international treaty, the cancellation of a law is equal to the cancellation of the internationl treaty. It is necessary to be noticed that an international treaty has two important principles, the first principle is pacta sunt servanda, and the second it rebus sic stantibus.

In Article 26 of Vienna Convention, it is formulated the meaning of pacta sunt servanda, that each treaty which bonds the parties involved and that treaty needs to be implemented well. This principle is not only applied to the implementation of specific treaties, but also applied to the international treaties such as the UN Charter. The confirmation of this principle in creating a convention is very important to ensure the compliance of the international treaty. The pacta sunt servanda principle is related to the sancity of treaties (the greatness of the treaty). In the past centuries, this principle was still firmly held, but in the latest era, this principle is no longer noticed. After many new countries established lately and the critical views about the problem related to unequal treaties, so it is doubtful whether the sanctity of treaties is still used (Preambule PBB Covenant). During the Vienna conference, some parties infer efforts to weaken the pacta sunt servanda by accepting the Rebus Sic Stantibus principle and Jus Cogens principle. These principles are used as the basic foundation by a country to declare not to be bound by an international treaty since it is not in line with the national law. Due to that case, the participants' proposals about the new article to rule the relationship between the national law and the compliance with the international treaty is accepted. ${ }^{10}$

Further in Article 27 of the Vienna Convention (Rebus Sic Stantibus) states that the parties of the treaty are not allowed to propose their own national law as an excuse to justify countries' act for not applying the international treaty. It is further mentioned that this Article 27 does not disadvantage the Article 46 of

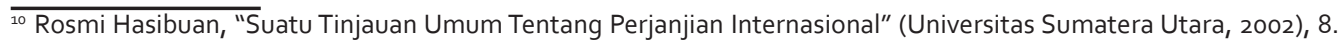


the covention. It can be concluded from Article 46 that a country is authorised to end a treaty as a way to covey disagreement for violating its national law. ${ }^{n}$ From the two principles, it can be concluded that:

1. An international treaty has to be treated with respect, especially when the international treaty has been made and ratified by Indonesia. The cancellation of an international treaty by one of the parties will result both political and economical matter which can effect the stability of the country's foreign policy.

2. Based on the Rebus Sic Stantibus principle in Article 27 of Vienna Convention, the cancellation of an international treaty due to the violation of a country's constitution/sovereignty, or the reason that the instrument of the international treaty ratification is in form of laws, therefore the cancellation of the treaty can be done. Due to the previous explanation, a step to avoid the laws of ratification of an international treaty by the Constitutional Court is needed.

Substantially, in a judicial review of the Law of ASEAN Charter, it emphasizes that the free market is the violation of the country's sovereignty in economics. As it is written on the sub-section in the theory of sovereignty which is above the sovereignty of a country has both positive and negative meaning, based on Boer Mauna, ${ }^{12}$ where the sovereignty of a country has two opposing points of view, both positive and negative aspects, which depend on the point of view of the country.

The sovereignty of a country is not absolute anymore, but in some cases it needs to honor other countries' sovereignty, which it is ruled by the international law. It is known as the Relative Sovereignty of State. In a context of international law, a sovereign state needs to be subject and to honor the international law and the sovereignty and border's integrity of other countries. ${ }^{13}$

If an international treaty which has been signed and ratified by Indonesia is cancelled by a party through a Constitutional Court, there will be consequences

\footnotetext{
11 Ibid.

12 Mauna, Hukum Internasional. Pengertian, Peranan Dan Fungsi Dalam Era Dinamika Global.

13 Isjwara, Pengantar Ilmu Politik, 89.
} 
or sanctions for the country, economically or politically, so it is urgent for Indonesia to formulate a new country's administration which can answer the problem related to the laws of ratification of an international treaty.

The proposal of Judicial Review of the law of ASEAN Charter which is filed in 2011 has clearly defined the sovereignty of a country negatively, where the emphasis of the proposal is the violation of a country's sovereignty in economics where a country is not supposed to be subject to the international law, in this case is the ASEAN Charter, but it needs to be concerned is "the violation of a county's sovereignty/consitution" as a result from following the international treaty. The following is the point of view of the former Director of International Treaty, Ministry of Foreign Affair of the Republic of Indonesia, Damos Dumoli Agusman:

Things to be noted, if the Constitutional Court decides that the ASEAN Charter is not in line with the 1945 Constitution of the State of Republic of Indonesia, the dilemma will arise and will be faced by Indonesia (as a country), that is honoring the 1945 Constitution of the State of Republic of Indonesia by violating the international law, or honoring the international law by violating the 1945 Constitution of the State of Republic of Indonesia. The reason is, based on the international law, Indonesia is not allowed to decline the treaty which has been ratified due to the violation of national law. ${ }^{14}$

From the previous point of view by Damos Damoli, it is explained that the position of a Constitutional Court is very important to decide the implementation of the international treaty, the verdict of the Constitutional Court has an important implication for the country if the verdict is cancelling the laws of ratification. Therefore, it is important to involve the Constitutional Court as a guardian of constitution when making the international treaty which is always done by the executive board of the country.

\subsection{A Specific Treatment for the Laws of Ratification of an International Treaty}

In solving the problem related to the laws of ratification of an international treaty, there are several efforts that can done. The first, a Judicial Preview can

\footnotetext{
${ }_{14}$ Agusman, "Dasar Konstitusional Perjanjian Internasional Mengais Latar Belakang Dan Dinamika Pasal 11 UUD 1945." See Judicial Review Law Number 38 of 2008 on Ratification of the Association of Southeast Asian Nations against the 1945 Constitution.
} 
be done as a solution to the problem. The following are solution to overcome the probem from the present research:

1. A specific treatment for the laws of ratification for an international treaty is needed. This treatment can be implemented by revising the law of the Republic of Indonesia No. 12 Year 2011 about the establishment of the laws and regulation; further, in relation to additional Judicial Preview's right of international treaties' bill which will be ratified by Indonesia, a normative change related to the establishment of laws and regulations needs to be in line with each other.

2. The existence of Judicial Preview which involves the Constitutional Court as a state institution whose role is to assess the norm of an international treaty before being adopted by the country through ratification. In relation to the Judicial Preview, Cecil Fabre states as follow:

Under judicial review constitutional courts are moved to act only if a claimant complains that one or several of constitutional rights have been violated. They cannot act before violated occurs, and this is sometimes to be their weakness. Under Constitutional Judicial Preview, by contrast, the constitutionality of the laws can be checked before they are implemented, which can partly pre-empt violation of rights and enable the constitutional courts to assess the law from wider point of view than that offered by individual cases they have to adjudicate..$^{15}$

A Judicial Preview is a real action to handle the problem of national administration against the law of international treaty by giving new rights for the Constitutional Court of the Republic of Indonesia to conduct a Judicial Preview for an international treaty which has been signed by delegations when the treaty is still in form of bill. There are several ways in order to give the new rights to the Constitutional Court such as the amandement of the 1945 Constitution (by inserting the new authority in Article 23 of the 1945 Constitution of the State of the Republic of Indonesia), the amandement of laws of The Constitutional Court, or deciding a judicial preview as a way to implement the state administration. Those three solutions are implemented with an exception 
where the bill of the international treaty, which gets a Judicial Preview by the Constitutional Court, does not have possibility to get any Judicial Review when the bill of the international treaty has been ratified or has been in form of law after going through a judicial preview.

The concept of Judicial Preview can be done in every draft of international treaty bill. There are ways done by the Constitutional Court to do a judicial preview toward the ratification of international treaty bill, such as:

1. The addition of the rights of the Constitutional Court in the 1945 Constitution of the State of the Republic of Indonesia.

2. Giving rights to the Constitutional Court through the constitution.

3. Through the state of administration, at the request of the People's Representatives Council.

By giving an authority to do a Judicial Preview toward the bill of the international treaty, the check and balances effort can be done since a Judicial Preview of the Constitutional Court becomes a tool to balance (stabilizer) the authority to make and ratify the international treaty which has been dominated by the executive board and the legislative board. A judicial preview of an international treaty can assure the establishment of constitutional supremacy.

\section{CONCLUSION}

There are several matters can be concluded in the present research, the first, the root of the problem from the unrelated condititon between the position of the international treaty and the laws and regulation hierarchy is the Dualism System which places the international treaty outside the legal system of the country, as the result the international treaty seems like a legal system which is excluded from the country's law. An international treaty can be adopted by a country to become a legal norm if it goes through ratification, but hierarchically as it is written in the Law of the Establishment of the Laws and Regulation, the international treaty is forced to be a law so the status of the laws of ratification can be examined by the Constitutional Court. 
The second, the allegiance of a country toward the treaty which has been made in an international law, logically it is not an act to decrease the sovereignty of a country (in positive way), before the international treaty is ratified, it is necessary to do some efforts to examine the provisions of the international treaty (constitutional review) so the violation of the constitution can be avoided. If the constitutional review of the laws of ratification of an international treaty keeps repeating, it is quite difficult for Indonesia to be involved in the international relationship especially in conventions which produce international treaty. Therefore, the sovereignty cannot be overvalued considering Indonesia also has national interest in the international political relationship. Judicial preview is the logical scenario to anticipate the cancellation of the laws of ratification of international treaties. The House of Representative asks the Constitutional Court to analyse the draft of the treaty of the international laws towards the 1945 Constitution. Judicial preview gives a new perspective about review on law of international ratification in Indonesia and keeps the international political relationship.

\section{Reference}

Adolf, Huala. Aspek-Aspek Negara Dalam Hukum Internasional. Jakarta: Rajawali Press, 1991.

Agusman, Damos Dumoli. "Dasar Konstitusional Perjanjian Internasional Mengais Latar Belakang Dan Dinamika Pasal 11 UUD 1945." Direktorat Jendral Hukum Dan Perjanjian Internasinal KementerianLuar Negeri Republik Indonesia 4 (2012): $1-7$.

Fabre, Cécile. Social Rights Under the Constitution: Government and the Decent Life. Oxford University Press: Clarendon Press, 2004.

Hasibuan, Rosmi. "Suatu Tinjauan Umum Tentang Perjanjian Internasional." Universitas Sumatera Utara, 2002.

Indrati, Maria Farida. Ilmu Perundang-Undangan (1). (Jenis, Fungsi, Materi Muatan). Yogyakarta: Kanisius, 2007.

Isjwara, Fred. Pengantar Ilmu Politik. Bandung: Binacipta, 1996. 
Judicial Review Law Number 38 of 2008 on Ratification of the Association of Southeast Asian Nations against the 1945 Constitution, No. 33/PUU-IX/2011 (2011).

Khaerudin. "MK Diminta Batalkan Ratifikasi Piagam Asean.” Kompas.Com, 2012. http://internasional.kompas.com/read/2012/11/23/2139259/MK.Diminta. Batalkan.Ratifikasi.Piagam.Asean.

Kusumaatmadja, Mochtar. Pengantar Hukum Internasional, Buku I Bagian Umum. Jakarta: Binacipta, 2010.

Mauna, Boer. Hukum Internasional. Pengertian, Peranan Dan Fungsi Dalam Era Dinamika Global. Bandung: Alumni, 2005.

Tumanggor, Simon. Judicial Review Undang-Undang Pengesahan Piagam Perhimpunan Bangsa-Bangsa Asia Tenggara Jendela Informasi Bidang Hukum Bidang Perdagangan. Jakarta: Kementerian Dalam Negeri RI, 2011. 